OPEN ACCESS

Edited by:

Ye Xin Koh,

Singapore General

Hospital, Singapore

Reviewed by:

Ivana Cataldo,

ULSS2 Marca Trevigiana, Italy

Giuseppe Bianco,

Catholic University of the Sacred

Heart, Italy

Pål-Dag Line,

University of Oslo, Norway

*Correspondence:

Michele Finott

mi6le@libero.it

Specialty section:

This article was submitted to

Surgical Oncology,

a section of the journal

Frontiers in Surgery

Received: 10 April 2021

Accepted: 21 June 2021

Published: 20 July 2021

Citation:

Finotti M, Vitale A, Gringeri E,

D'Amico FE, Boetto $R$, Bertacco $A$, Lonardi S, Bergamo F, Feltracco $P$ and Cillo U (2021) Colon Rectal Liver

Metastases: The Role of the Liver

Transplantation in the Era of the

Transplant Oncology and Precision

Medicine. Front. Surg. 8:693387.

doi: 10.3389/fsurg.2021.693387

\section{Colon Rectal Liver Metastases: The Role of the Liver Transplantation in the Era of the Transplant Oncology and Precision Medicine}

\author{
Michele Finotti ${ }^{1 *}$, Alessandro Vitale ${ }^{1}$, Enrico Gringeri ${ }^{1}$, Francesco Enrico D'Amico ${ }^{1}$, \\ Riccardo Boetto ${ }^{1}$, Alessandra Bertacco ${ }^{1}$, Sara Lonardi ${ }^{2}$, Francesca Bergamo ${ }^{2}$, \\ Paolo Feltracco ${ }^{3}$ and Umberto Cillo ${ }^{1}$ \\ ${ }^{1}$ University of Padova, Transplantation and Hepatobiliary Surgery, Padua, Italy, ${ }^{2}$ Unit of Oncology 1, Department of \\ Oncology, Veneto Institute of Oncology IOV - Istituto di Ricovero e Cura a Carattere Scientifico, Padua, Italy, ${ }^{3}$ Anesthesia and \\ Intensive Care Unit, Azienda Ospedaliera di Padova, Padua, Italy
}

The development of liver metastases in colon rectal cancer has a strong impact on the overall survival (OS) of the patient, with a 5 -year survival rate of $5 \%$ with palliative treatment. Surgical resection combined with pharmacological treatment can achieve a 5 -year OS rate of $31-58 \%$. However, in only $20 \%$ of patients with colon rectal liver metastases (CRLMs), liver resection is feasible. In highly selected patients, recent trials and studies proved that liver transplantation (LT) for non-resectable CRLM is a surgical option with an excellent long-term OS. The paper aims to review the indications and outcome of $L T$ for $C R L M s$, with a special focus on immunosuppressive therapy and the management of local and extrahepatic recurrence after LT.

Keywords: liver resection, transplant benefit, prioritization, immunosopressive therapy, recurrence

\section{INTRODUCTION}

Colorectal cancer (CRC) is the third most common tumor worldwide. In $20-30 \%$ of cases, the liver is affected by metastases, strongly undermining the survival of patients. If compared to other organs involvement, liver metastases are associated with a higher decrease in the overall survival (OS): The median OS is about $8-10$ months, with a 5 -year survival rate of $5 \%$ with palliative treatment (1).

Pharmacological therapy alone is rarely effective in the presence of ColoRectal Liver Metastases (CRLMs). The current treatment of choice for CRLMs is represented by surgical resection, combined with systemic chemotherapy, achieving a 5 -year OS of $31-58 \%(2,3)$.

Numerous surgical and radiological options are available: liver resection with tissue-sparing techniques, multistage hepatectomies, ablative therapies such as microwave or radio-frequency ablation, irreversible electroporation, regional hepatic intra-arterial chemotherapy, stereotactic radiotherapy, and radio-embolization.

Control of the local disease with an aggressive surgical approach to the CRLMs is supported by the literature: Liver partition and portal vein ligation for staged hepatectomy (ALPPS), repeated resection, or two-stage hepatectomies are especially indicated for patients with insufficient future liver remnants (4-7). 
Despite the recent evolution in hepatobiliary surgery techniques, however, in almost $80 \%$ of patients with CRLMs, liver resection is still not feasible, especially due to the localization and number of nodules (3).

The definition of non-resectable liver metastases is still not well-established and under evolution.

Recent guidelines define resectable as a tumor that can be resected completely with adequate margin (R0), leaving a sufficient liver remnant with adequate vascular inflow and outflow as well as biliary drainage. In particular, localization, dimension of the metastases, the presence of extrahepatic disease, and vascular invasion (possibility of reconstruction of vena cava and/or portal vein) should no longer restrict the indication to liver resection (8).

However, the postoperative and oncological outcomes are strictly correlated with an appropriate patient selection. Biological factors, in particular tumor biology, liver tumor burden, and number of lesions, are critical factors that heavily affect the survival of a patient.

Appropriate scores can predict the OS and the risk of recurrence, helping the selection of patients, such as Fong, Nordlinger, Nagashima, and Konopke scores (9-12). High-risk patients can benefit most from neoadjuvant chemotherapy before liver resection.

In this setting and in highly selected patients, recent trials and studies proved that liver transplantation (LT) for non-resectable CRLM is a surgical option with an excellent long-term OS, offering a R0 procedure by replacing the liver (13).

The role of LT in the context of liver tumors has been recently reconsidered and is in constant evolution. According to the concept of Transplant Oncology, the long-term outcome after LT for malignant liver tumors should be similar to those of LT for the non-malignant indication (14-17).

The first series of LT for CRLM have been proposed in the 1980s and the 1990s, with poor outcomes. At the time, the peri- and postoperative mortality after LT reached 30\%, the liver recurrence was described in $40 \%$ of the patients within 1 year and the 5 -year OS ranged from 0 to $18 \%$. In the 1990s, Muhlbacher et al. reported the largest series of CRLM treated with LT, with a 5 -year survival rate of only $12 \%$ (18).

Due to these results, LT for CRLM was considered an unacceptable waste of resources, especially in an era of shortages of donor grafts.

Since the 1980s and 1990s, however, surgical and especially medical management dramatically changed. The improvement of pharmacological therapies for CRLM promoted the use of oxaliplatin and irinotecan in combination with monoclonal antibodies (antivascular endothelial growth factor receptor or antiepidermal growth factor receptor), reaching excellent local disease control (19-22).

A better understanding of the predictive factors associated with local recurrences and OS helped to better select patients who were eligible for LT with a good outcome. In the last decades, more refined intra- and postoperative management following LT achieved a significant reduction in the mortality and morbidity related to the surgical procedure $(9,23-25)$.
Furthermore, the use of immunosuppressive agents with antineoplastic abilities (mTOR-mammalian target of rapamycin inhibitors) helped to improve the patient outcome (26-28).

In our paper, we intend to review the most recent available data, indications, and outcomes of LT for CRLMs, with a special focus on immunosuppressive therapy and the management of local and extrahepatic recurrence after LT.

\section{THE SECONDARY CANCER I STUDY AND SECA II: FROM THE PROOF OF CONCEPT TO THE CLINICAL TRIAL}

In 2013, the SECA I was the first prospective trial that reported 21 patients with liver limited disease (29). Non-resectable CRLMs were treated with LT after at least 6 weeks of neoadjuvant chemotherapy. In SECA I, the inclusion criteria was relatively broad (see Table 1). The study reported a Kaplan-Meier estimate of 1-, 3-, and 5-year OS of 95, 68, and 60\%, respectively, with a median follow-up of 27 months (range: 8-60 months). Compared with mere chemotherapy (Nordic VII trial), the improvement in the OS with LT was dramatic: The 5-year OS rate was $60 \%$ in patients undergoing LT, and it was $9 \%$ in patients treated only with chemotherapy (30).

Tumor $<5.5 \mathrm{~cm}$, CEA $<80 \mathrm{ng} / \mathrm{L}$, major than 2 years between resection of primary tumor and LT, and evidence of tumor partial response or stable disease on chemotherapy have been identified as important factors leading to a better OS after LT (31).

These variables were included in the Oslo score, an important tool that helps in the stratification of the patients undergoing LT for CRLMs and identifies patients with favorable tumor biology. Oslo score numbered the risk factors from 0 to 4 stratifying the patients into three subgroups $(0-1,2-3$, and 4$)$. To note, variables included in Olso score were similar to Fong's Clinical Risk Score (FCRS) for recurrence after liver resection for CRLMs (see Table 2). Patients with an Oslo risk score of 4 had a 5-year OS of $0 \%$ (31).

However, as recently acknowledged by Smedman et al., the Oslo score reveals important limitations. It does not take into account some clinicopathological features of the disease that are dramatically relevant for its prognoses, such as BRAF mutation status, histological differentiation, location of the primary tumor (right-sided, left-sided, or rectal), and node status (32).

In the SECA II, with more strictly selection criteria than SECA I (see Table 1), the authors obtained a Kaplan-Meier OS at 1, 3, and 5 years of $100 \%, 83$, and $83 \%$, respectively, with a median follow-up of 36 months (range 5-60 months).

The CRLMs were confirmed by CT, MRI, and positron emission tomography (18) (F-FDG PET/CT scan), with at least $10 \%$ response to $\mathrm{CT}$ and with a time interval between diagnoses of LT of more than 1 year (33). CT scan is more often applied compared to MRI, since thoracic staging is better evaluated with CT scan, while PET/CT scan is mandatory, considering also its prognostic value (34). 
TABLE 1 | Comparison of the published result on LT for CRLMs.

\begin{tabular}{|c|c|c|c|c|c|}
\hline \multicolumn{2}{|l|}{ Variables } & SECA I NCT01311453 & $\begin{array}{l}\text { SECA II study } \\
\text { NCT01479608 }\end{array}$ & $\begin{array}{l}\text { SECA II study D arm } \\
\text { NCT01479608 }\end{array}$ & Compagnons Hépato-Biliaires \\
\hline \multicolumn{2}{|l|}{ Type of study } & Prospective pilot study & Prospective study & Prospective study & Retrospective cohort study \\
\hline \multicolumn{2}{|l|}{ Country } & Norway & Norway & Norway & France \\
\hline \multicolumn{2}{|l|}{ Start } & 10/2006 & $5 / 2012$ & $5 / 2012$ & 10/1995 \\
\hline \multicolumn{2}{|l|}{ State } & Finished & Recruiting & Recruiting & Finished \\
\hline \multicolumn{2}{|c|}{ Definition of non-resectability } & $\begin{array}{l}\text { Based on the location of metastases } \\
\text { and the volume of the future liver } \\
\text { remnant }\end{array}$ & - & - & - \\
\hline \multicolumn{2}{|c|}{ Number of participants } & 21 & 15 & 10 & 12 \\
\hline \multicolumn{2}{|c|}{ Location of the primary tumor } & $\begin{array}{l}\text { Colon (52\%) } \\
\text { Rectum (48\%) }\end{array}$ & $\begin{array}{l}\text { Colon (73.3\%) } \\
\text { Rectum (26.6\%) }\end{array}$ & $\begin{array}{l}\text { Colon (90\%) } \\
\text { Rectum (10\%) }\end{array}$ & $\begin{array}{l}\text { Colon }(91.6 \%) \\
\text { Rectum (8.3\%) }\end{array}$ \\
\hline Stage of & $\mathrm{T} 1$ & $4.7 \%$ & $6.6 \%$ & $0 \%$ & $8.3 \%$ \\
\hline \multirow[t]{6}{*}{ primary tumor } & $\mathrm{T} 2$ & $9.5 \%$ & $13.3 \%$ & $20 \%$ & $8.3 \%$ \\
\hline & T3 & $76.1 \%$ & $73.3 \%$ & $70 \%$ & $66.6 \%$ \\
\hline & $\mathrm{T} 4$ & - & $6.6 \%$ & $10 \%$ & $16.6 \%$ \\
\hline & NO & $33.3 \%$ & $53.3 \%$ & $20 \%$ & $41.6 \%$ \\
\hline & $\mathrm{N} 1$ & $33.3 \%$ & $40 \%$ & $0 \%$ & $41.6 \%$ \\
\hline & N2 & $33.3 \%$ & $6.6 \%$ & $80 \%$ & $16.6 \%$ \\
\hline \multicolumn{2}{|l|}{ KRAS } & - & $7.1 \%$ & $30 \%$ & - \\
\hline \multirow{5}{*}{$\begin{array}{l}\text { Cancer } \\
\text { treatments } \\
\text { before LT }\end{array}$} & $\begin{array}{l}\text { Two or more } \\
\text { lines }\end{array}$ & $57 \%$ & $53.3 \%$ & $100 \%$ & $75 \%$ \\
\hline & Principal CT & Irinotecan and oxaliplatin & 5-FU and irinotecan & 5-FU and irinotecan & Irinotecan and oxaliplatin \\
\hline & $\begin{array}{l}\text { Previous } \\
\text { radiation }\end{array}$ & $14.2 \%$ & No & $10 \%$ & No \\
\hline & $\begin{array}{l}\text { Previous liver } \\
\text { resection }\end{array}$ & $19 \%$ & $26.6 \%$ & $20 \%$ & $83.3 \%$ \\
\hline & $\begin{array}{l}\text { Previous local } \\
\text { treatment }\end{array}$ & $9.5 \%$ & $13.3 \%$ & $20 \%$ & $8.3 \%$ \\
\hline Time of liver & Metachronous & $19 \%$ & $6.6 \%$ & $0 \%$ & $25 \%$ \\
\hline metastases & Synchronous & $81 \%$ & $93.3 \%$ & $100 \%$ & $75 \%$ \\
\hline \multicolumn{2}{|c|}{ Time from primary surgery to LT } & 36 months (16-59) & 22.6 months $(2.3-111.3)$ & 16.5 months (4-173) & 41 months (12-97) \\
\hline
\end{tabular}


TABLE 1 | Continued

\begin{tabular}{|c|c|c|c|c|}
\hline Variables & SECA I NCT01311453 & $\begin{array}{l}\text { SECA II study } \\
\text { NCT01479608 }\end{array}$ & $\begin{array}{l}\text { SECA II study D arm } \\
\text { NCT01479608 }\end{array}$ & Compagnons Hépato-Biliaires \\
\hline \multirow[t]{2}{*}{ Type of Graft } & Whole liver from deceased donor & Whole liver from deceased donor & $\begin{array}{l}\text { Whole liver from } \\
\text { extended criteria deceased donor }\end{array}$ & $\begin{array}{l}\text { Whole liver from deceased domino } \\
\text { donor }\end{array}$ \\
\hline & & & $\begin{array}{l}\text { Split liver from } \\
\text { extended criteria deceased donor }\end{array}$ & Living donor liver transplantation \\
\hline Inclusion criteria & $\begin{array}{l}\text { - Completed radical excision of the } \\
\text { primary tumor } \\
\text { - ECOG score } 0 \text { or } 1 \\
\text { - Minimum } 6 \text { weeks of CT. } \\
\text { - Absence of extrahepatic disease } \\
\text { was assessed by chest, abdominal, } \\
\text { and pelvic computed tomographic } \\
\text { (CT) scans, whole-body positron } \\
\text { emission tomographic/CT scan, } \\
\text { and bone scan. }\end{array}$ & $\begin{array}{l}\text { - Standard surgical resection } \\
\text { procedure of primary tumor with } \\
\text { adequate resection margins, } \\
\text { including circumferential resection } \\
\text { margins (CRM) of at least } 2 \mathrm{~mm} \text { for } \\
\text { rectal cancer } \\
\text { - ECOG } 0 \text { or } 1 \\
\text { - At least } 1 \text {-year time span from CRC } \\
\text { diagnosis and date of being listed } \\
\text { on the transplantation list. } \\
\text { - No extrahepatic metastatic disease } \\
\text { or local recurrence according to } \\
\text { PET/CT scan, CT, or MR } \\
\text { (thorax/abdomen/pelvis) scan } \\
\text { within } 4 \text { weeks before the faculty } \\
\text { meeting } \\
\text { - Histologically verified } \\
\text { adenocarcinoma in colon or rectum } \\
\text { - No signs of local recurrence judged } \\
\text { by colonoscopy/CT colography } \\
\text { within } 12 \text { months before the faculty } \\
\text { meeting } \\
\text { - Satisfactory blood tests* } \\
\text { - Relapse of liver metastases after } \\
\text { second liver resection or liver } \\
\text { metastases not eligible for curative } \\
\text { liver resection } \\
\text { - Received first-line treatment } \\
\text { - Before the start of CT, no lesion } \\
\text { should be }>10 \mathrm{~cm} \text {, if }>30 \text { lesions } \\
\text { all should be }<5 \mathrm{~cm} \text {, and the } \\
\text { patients should have at least } 30 \% \\
\text { response by RECIST criteria. } \\
\text { - At least } 10 \% \text { response (RECIST } \\
\text { criteria) on CT. } \\
\text { - If }<10 \% \text { response on CT may be } \\
\text { included if they obtain at least } 20 \% \\
\text { response after TACE (DEB-IRI) or } \\
\text { by } 90 Y \text {-spheres. }\end{array}$ & $\begin{array}{l}\text { The same as SECA-II, but ALSO } \\
\text { include patients: } \\
\text { - Who had resectable pulmonary } \\
\text { metastases or undergone resection } \\
\text { of pulmonary metastases } \\
\text { - Received CT before inclusion, but } \\
\text { there was no prerequisite regarding } \\
\text { the response to CT at time of being } \\
\text { listed for LT } \\
\text { - No time from primary diagnosis } \\
\text { to LT }\end{array}$ & $\begin{array}{l}\text { - Response and no progression under } \\
\text { CT } \\
\text { - No signs of extrahepatic metastatic } \\
\text { disease or local recurrence } \\
\text { - Relapse of liver metastases after } \\
\text { second liver resection or liver } \\
\text { metastases not eligible for curative } \\
\text { liver resection } \\
\text { - Salvage procedures: massive } \\
\text { bleeding (and packing) following } \\
\text { liver resection, failed ALPPS } \\
\text { procedure and for post-resection } \\
\text { liver failure }\end{array}$ \\
\hline
\end{tabular}




\begin{tabular}{|c|c|c|c|c|c|}
\hline \multicolumn{6}{|c|}{ TABLE 1 | Continued } \\
\hline \multicolumn{2}{|l|}{ Variables } & SECA I NCT01311453 & $\begin{array}{l}\text { SECA II study } \\
\text { NCT01479608 }\end{array}$ & $\begin{array}{l}\text { SECA II study D arm } \\
\text { NCT01479608 }\end{array}$ & Compagnons Hépato-Biliaires \\
\hline \multicolumn{2}{|c|}{ Main exclusion criteria } & $\begin{array}{l}\text { - Weight loss of more than } 10 \% \\
\text { - Standard contraindications for liver } \\
\text { transplantation and/or } \\
\text { other malignancies }\end{array}$ & $\begin{array}{l}\text { - Weight loss }>10 \% \text { the last } 6 \\
\text { months } \\
\text { - BMI > } 30 \\
\text { - Other malignancies } \\
\text { - Known hypersensitivity to } \\
\text { rapamycin } \\
\text { - Prior extrahepatic metastatic } \\
\text { disease or local relapse } \\
\text { - Not standard preoperative, } \\
\text { peri-operative, or postoperative } \\
\text { treatment for the primary CRC } \\
\text { - Palliative resection of primary CRC } \\
\text { tumor } \\
\text { - Women who are pregnant or breast } \\
\text { feeding } \\
\text { - Any reason why, in the opinion of } \\
\text { the investigator, the patient should } \\
\text { not participate }\end{array}$ & As SECA-\| & $\begin{array}{l}\text { - Standard contraindications for liver } \\
\text { transplantation and/or } \\
\text { other malignancies }\end{array}$ \\
\hline \multicolumn{2}{|c|}{ Risk stratification } & The Fong Clinical Risk Score (FCRS) & FCRS and the Oslo score & FCRS and the Oslo score & - \\
\hline \multicolumn{2}{|c|}{ Immunosuppressive protocol } & $\begin{array}{l}\text { Sirolimus, mycophenolate mofetil, } \\
\text { corticosteroids, and induction } \\
\text { with basiliximab. Sirolimus from the } \\
\text { first POD, level of } 5 \text { to } 10 \mathrm{ng} / \mathrm{mL} \\
\text { during the first } 4 \text { weeks and } 10 \text { to } 20 \\
\mathrm{ng} / \mathrm{mL} \text { thereafter }\end{array}$ & $\begin{array}{l}\text { Induction with basiliximab, tacrolimus } \\
\text { the first } 4-6 \text { weeks, and then } \\
\text { conversion to sirolimus. }\end{array}$ & $\begin{array}{l}\text { Induction with basiliximab, } \\
\text { corticosteroids, mycophenolate, and } \\
\text { tacrolimus the first } 4-6 \text { weeks, then } \\
\text { conversion from tacrolimus to } \\
\text { sirolimus, level of } 5-10 \mathrm{ng} / \mathrm{mL} \text { during } \\
\text { the first } 4 \text { weeks and } 10-20 \mathrm{ng} / \mathrm{mL} \\
\text { thereafter }\end{array}$ & mTOR inhibitors in $66.6 \%$ of patients \\
\hline \multirow[t]{7}{*}{ Complications } & Grade I & $5 \%$ & - & $20 \%$ & - \\
\hline & Grade II & $29 \%$ & - & $20 \%$ & $25 \%$ \\
\hline & Grade IIla & $10 \%$ & $13.3 \%$ & - & - \\
\hline & Grade Illb & $24 \%$ & $20 \%$ & $30 \%$ & $8.3 \%$ \\
\hline & Grade IVa & $4 \%$ & $13.3 \%$ & $20 \%$ & $16.6 \%$ \\
\hline & Grade IVb & - & - & $10 \%$ & - \\
\hline & Grade V & - & - & - & $8.3 \%$ \\
\hline \multirow[t]{4}{*}{ Results } & Median FU & 27 months (8-60 months) & 36 months (5-60) & 23 months & 26 months \\
\hline & OS 1 y & $95 \%$ & $100 \%$ & $70 \%$ & $83 \%$ \\
\hline & $3 y$ & $68 \%$ & $83 \%$ & $40 \%$ & $62 \%$ \\
\hline & $5 y$ & $60 \%$ & $83 \%$ & - & $50 \%$ \\
\hline
\end{tabular}




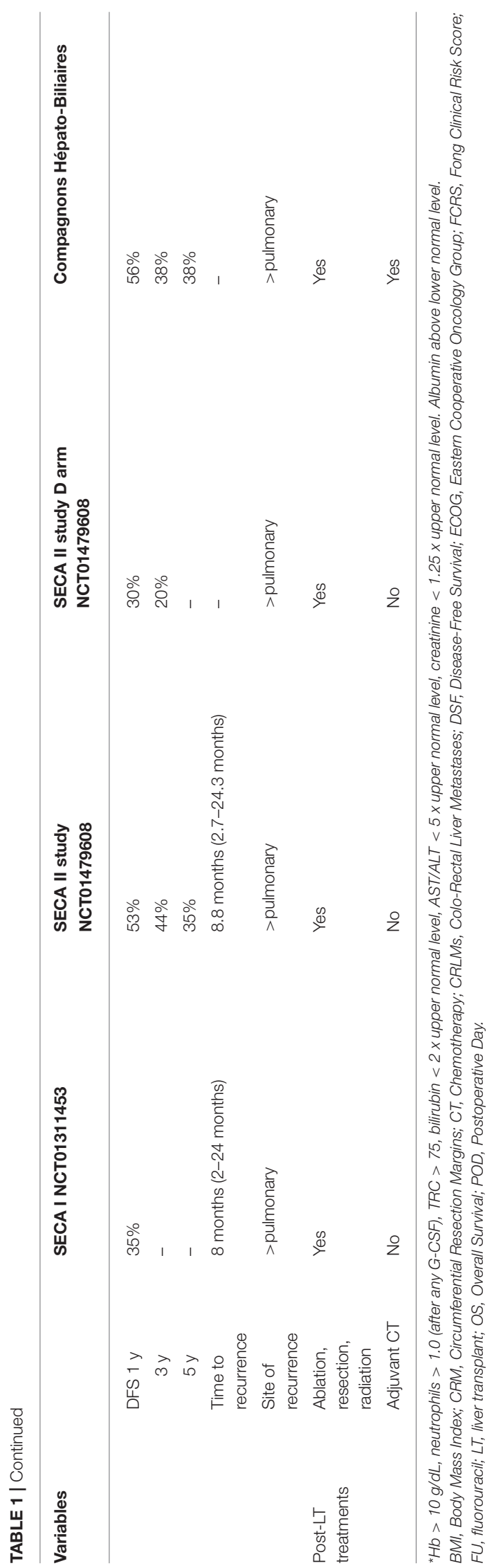

TABLE 2 | Oslo and Fong scores: clinical risk prognostic scores of LT for CRLMS.

Oslo score (0-4) $\quad$ Fong clinical risk score (FCRS)
(0-5)

Tumor diameter $>5.5 \mathrm{~cm}$

CEA $>80 \mathrm{ug} / \mathrm{L}$

Less than 2-year interval between

primary resection and $\mathrm{LT}$

Progressive disease at time of $\mathrm{LT}$

Largest tumor $>5 \mathrm{~cm}$

CEA $>200 \mathrm{ug} / \mathrm{L}$

Synchronous Disease (primary to liver recurrence $<12$ months)

Node-positive primary

More than 1 liver metastases

\section{COLON RECTAL LIVER METASTASES AS A NEW INDICATION TO LT: THE CHALLENGING OF THE PRIORITIZATION}

The SEcondary CAncer I study II and I were conducted under a unique geographical condition: The Norwegian system allows low waitlist mortality $(<3 \%)$ and short waiting times. Most of the patients with high MELD get a transplant within 3 months, thanks to the good liver donation rate and the different epidemiology of liver diseases compared to the rest of the Western World (35). In the rest of the world, the indication of LT for CRLM as a viable treatment option, on the contrary, must deal with organ shortage. The major concern, therefore, was that adding a new indication for LT could affect negatively the waiting lists, already burdened by high mortality for the long waiting time. However, using strict inclusion criteria to select properly patients, the impact on the waiting list would be not unacceptable. In the United States, it was estimated that LT for CRLMs would represent $\sim 3 \%$ of the transplants performed in the United States per year (36).

Furthermore, the expanding use of machine perfusion and the recent improvement in marginal donor management may limit liver graft shortage. An ongoing clinical trial is evaluating the utilization of extended criteria liver grafts from donors (ECD) not utilized for approved LT indications (SOULMATE, NCT04161092). Smedman et al. confirmed that, in the SECA-II D arm, the use of ECD grafts appears to be safe (32).

In this setting, two important studies proposed alternative options to increase the donor pool. The RAPID concept (37) and the use of living donor (Toronto Protocol) have been recently proposed and are currently under investigation (38).

In the RAPID concept, a left lateral split liver graft from a deceased or living donor is implanted in the recipient affected by non-resectable CRLMs after left hepatectomy through APOLT technique (auxiliary partial orthotopic LT) (39). The right portal vein is ligated to induce hypertrophy with an adequate portal and arterial flow/pressure management, and a delayed hepatectomy is performed $(15,37,40)$. Ongoing clinical trials are based precisely on this technique (NCT02215889 and NCT04865471).

Inspired by the same concept, Konigsrainer et al. proposed to use the left lateral segment from living donor [LIVER-T(W)OHEAL] (41). Living donation allows expanding the LT indication without affecting the deceased donor pool. Furthermore, the use of only later lobes reduces the risks for the donors (42). 
Recently, Ravaioli et al. proposed an alternative to the RAPID technique. Their procedure consists of a heterotopic LT of segments $2-3$ in the splenic fossa after splenectomy with delayed hepatectomy after regeneration of the transplanted graft. The supposed advantage of this procedure compared to the RAPID technique is no native liver manipulation and possible application in the case of previous liver resections $(43,44)$.

These new procedures mixed the latest development in hepatobiliary and LT surgery, using a combination of living donor liver transplantation, APOLT (39), and associating liver partition and portal vein ligation for staged hepatectomy (ALPPS) techniques $(45,46)$.

A comparison of the ongoing clinical trials on LT for CRLMs is summarized in Table 3.

\section{MANAGEMENT OF THE IMMUNOSUPPRESSIVE THERAPY AND RECURRENCES}

Metastatic CRC is considered a systemic disease, and the risk of recurrence after surgical therapy is high. Twenty percent of patients affected by CRLMs are liable to liver resections (47) but after resection, up to $60-70 \%$ of them will develop recurrence within 3 years $(48-50)$.

Starting from this premise, recurrence after LT is expected. In addition, immunosuppressive therapy after LT has been thought to predispose to malignancy and recurrence after LT. Immunosuppression, in particular, mTOR (a mammalian target of rapamycin) inhibitors, has been correlated with incisional hernia, HAT, rejections, and risk of cancer development.

In the SECA-I and SECA-II, mTOR inhibitor was the main immunosuppressive agent used. HAT, potentially related to mTOR inhibitors use, was observed only in one patient. The increase of postoperative anticoagulation restricted the arterial complications to the technical aspect, leading, however, to increasing episodes of hemorrhage and hematomas (31). The role of immunosuppression in the development of metastases has been evaluated, pointing out a comparable growth rate of the metastases in immunosuppressed and immunocompetent patients (51). However, more data will be necessary to understand the role of immunosuppression and the relationship with recurrence after LT.

To note, the pattern of recurrence and their natural history after LT is different compared to that of recurrence after liver resection for CRLM (33).

After hepatectomies for CRLM, most of the recurrence appeared within the remnant liver, with only $26 \%$ of patients developing isolated lung metastases (6). On the other side, after LT, the recurrence is mostly pulmonary, isolated, and liable to curative surgery $(13,52,53)$. These results suggest that total hepatectomy and LT may have a favorable recurrence profile compared to recurrence after liver resection (51).

In the SECA I, the median time of recurrence was 8 months (range, 2-24 months), reflected by the low disease-free survival (DFS). However, most of the patients benefit from surgical, radiofrequency, or radiation treatment of the local recurrence with curative intent. Pulmonary metastases are the most frequent site of progression, but are usually solitary with slow development (31). In the SECA II, with more strict inclusion criteria, four of the 15 patients were observed for more than 30 months without a relapse, and pulmonary recurrences are the only or primary location in $75 \%$ of patients. The same study confirmed the slow growth rate of the recurrence, especially for the pulmonary metastases, with a median time of 21 months from detection to resection.

Based on these preliminary data, the recurrence after LT for CRLMs seems to have different behavior and impact on the patient outcome compared, for example, to recurrence in patients affected by HCC. Based on the SECA-I study, Dueland et al. showed that in a low-risk patient who underwent LT for CRLM with subsequent recurrence, the OS was better than in patients affected by recurrence after LT for HCC (54).

DFS in the LT for CRLMs is not a good tool to predict the patient outcome and the efficacy of LT in CRLMs, because recurrence alone is not correlated with low OS (33).

Recently, Compagnons Hepato-Biliaires demonstrated that, with carefully selected patients, a long-term DFS can be achieved. The authors reported that six of 12 recipients alive free of recurrence at 7-108 months after LT for CRLMs. In these patients, multiple courses of CT and liver resection were performed before LT. Conversely, the other six of 12 patients that undergone LT for "compassionate" indications (LT after massive bleeding, post-resection liver failure) showed recurrence within 18 months with a significantly worse DFS. In the whole cohort, the OS was $83 \pm 11 \%, 62 \pm 15 \%$, and $50 \pm 16 \%$ at 1,3 , and 5 years, after a median follow-up of $26(0-108)$ months. As for SECA study, the predictors of recurrence were the last pre-transplant CEA level ( $\geq 80$ vs. $<80 \mu \mathrm{g} / \mathrm{l}$ ) and the time between resection of primary cancer and transplantation ( $\geq 24$ vs. $<24$ months). To note, the size of the largest metastasis at transplant ( $\geq 5.5$ vs. $<5.5 \mathrm{~cm}$ ) failed to predict DFS (55).

\section{CONCLUSION}

One of the major controversies is how to integrate the LT for CRLM in the context of numerous available surgical options (local liver treatments, hepatic resection, chemo-, or radio-embolization), how to choose the best one or the best combination of them, and how to establish that the CRLM isn't resectable and liable to LT. A recent multidisciplinary consensus from the COLLISION Trial Group created an algorithm with specific resectability and ablatability criteria for the treatment of CRLMs (56). S. Jegatheeswaran and A. Siriwardena in their comment on the SECA-II study pointed out that the concept of resectability is prone to a variation. In the SECA-II, $60 \%$ of patients had five or fewer metastases with five patients having three or fewer lesions, but considered unresectable due to local recurrence after previous multiple treatments (liver resection and/or ablation) (57). However, the author acknowledged the possible variable interpretation of liver resectability $(57,58)$. The same concern was raised by Azoulay and $\operatorname{Lim}(36)$. 


\begin{tabular}{|c|c|c|c|c|c|c|c|c|c|}
\hline & $\begin{array}{l}\text { Toronto NCT } \\
02864485\end{array}$ & $\begin{array}{l}\text { TRANSMET } \\
\text { NCT02597348 }\end{array}$ & $\begin{array}{l}\text { RAPID } \\
\text { NCT02215889 }\end{array}$ & $\begin{array}{l}\text { LIVER-T(W)O- } \\
\text { HEAL } \\
\text { NCT03488953 }\end{array}$ & $\begin{array}{l}\text { SOULMATE } \\
\text { NCT04161092 }\end{array}$ & $\begin{array}{l}\text { SECA III } \\
\text { NCT03494946 }\end{array}$ & $\begin{array}{l}\text { COLT } \\
\text { NCT03803436 }\end{array}$ & $\begin{array}{l}\text { RAPID-PADOVA } \\
\text { NCT04865471 }\end{array}$ & $\begin{array}{l}\text { MELODIC } \\
\text { NCT04870879 }\end{array}$ \\
\hline Type of study & Prospective cohort & $\begin{array}{l}\text { Prospective, } \\
\text { multicenter } \\
\text { randomized } \\
\text { parallel }\end{array}$ & Prospective & $\begin{array}{l}\text { Prospective } \\
\text { bi-institutional, } \\
\text { one-arm trial. }\end{array}$ & $\begin{array}{l}\text { Randomized } \\
\text { controlled, } \\
\text { open-label, } \\
\text { multicenter study }\end{array}$ & $\begin{array}{l}\text { Randomized study } \\
\text { standard }\end{array}$ & $\begin{array}{l}\text { Multicenter, } \\
\text { non-randomized }\end{array}$ & $\begin{array}{l}\text { Prospective, } \\
\text { multicenter, } \\
\text { non-randomized }\end{array}$ & $\begin{array}{l}\text { Prospective } \\
\text { multicenter, } \\
\text { non-randomized }\end{array}$ \\
\hline Design & LDLT + CT vs. CT & CT + LT vs. CT & $\begin{array}{l}\text { Liver resection and } \\
\text { partial section } \\
\text { S2/3 transplanted } \\
\text { with two-stage } \\
\text { hepatectomy }\end{array}$ & $\begin{array}{l}\text { LDLT with } \\
\text { two-stage } \\
\text { hepatectomy }\end{array}$ & $\begin{array}{l}\text { LT with } E C D+C T \\
\text { vs. CT }\end{array}$ & $\begin{array}{l}\text { LT vs. CT, TACE, } \\
\text { SIRT or other } \\
\text { available treatment } \\
\text { options }\end{array}$ & $\mathrm{LT}+\mathrm{CT}$ vs. CT & $\begin{array}{l}\text { Liver resection and } \\
\text { partial section } \\
\text { S2/3 transplanted }\end{array}$ & $\mathrm{LT}+\mathrm{CT}$ vs. CT \\
\hline Country & Canada & France & Norway & Germany & Swedish & Norway & Italy & Italy & Italy \\
\hline Start & $8 / 2016$ & 9/2015 & $6 / 2014$ & $5 / 2018$ & $2 / 2020$ & 12/2016 & $1 / 2019$ & To be determined & To be determined \\
\hline State & Recruiting & Recruiting & Recruiting & Recruiting & Not yet recruiting & Recruiting & Recruiting & Not yet recruiting & Not yet recruiting \\
\hline $\begin{array}{l}\text { Definition of non } \\
\text { resectability }\end{array}$ & $\begin{array}{l}\text { Bilateral and } \\
\text { non-resectable } \\
\text { CRLMs }\end{array}$ & $\begin{array}{l}\text { Independent } \\
\text { Steering } \\
\text { Committee } \\
\text { including } \\
\text { hepatobiliary } \\
\text { surgeons, } \\
\text { oncologists, } \\
\text { radiologists, and } \\
\text { hepatologists }\end{array}$ & $\begin{array}{l}\text { Liver metastases, } \\
\text { not amenable to } \\
\text { liver resection }\end{array}$ & $\begin{array}{l}\text { Unresectability is } \\
\text { evaluated by } \\
\text { experienced, } \\
\text { independent } \\
\text { hepatobiliary } \\
\text { surgeons }\end{array}$ & $\begin{array}{l}\text { Patients with } \\
\text { non-resectable, } \\
\text { non-ablatable liver } \\
\text { metastases }\end{array}$ & $\begin{array}{l}\text { Liver metastases, } \\
\text { not amenable to } \\
\text { liver resection }\end{array}$ & $\begin{array}{l}\text { Liver metastases } \\
\text { not eligible for } \\
\text { curative liver } \\
\text { resection }\end{array}$ & $\begin{array}{l}\text { Liver metastases, } \\
\text { not amenable to } \\
\text { liver resection }\end{array}$ & $\begin{array}{l}\text { Liver metastases, } \\
\text { not amenable to } \\
\text { liver resection }\end{array}$ \\
\hline $\begin{array}{l}\text { Type of graft and } \\
\text { donor }\end{array}$ & $\begin{array}{l}\text { Living donor liver } \\
\text { transplantation }\end{array}$ & $\begin{array}{l}\text { Whole liver from } \\
\text { deceased donor. }\end{array}$ & $\begin{array}{l}\text { Living donor } \\
\text { segment 2/3 } \\
\text { Stage 1: S2-S3 } \\
\text { removed and liver } \\
\text { donor implanted. } \\
\text { Stage 2: After } \\
\text { growth of donor } \\
\text { segments, the } \\
\text { remaining liver } \\
\text { segments of the } \\
\text { recipient were } \\
\text { removed }\end{array}$ & $\begin{array}{l}\text { Living donor } \\
\text { segment } 2 / 3 \text { with } \\
\text { two-stage } \\
\text { hepatectomy }\end{array}$ & $\begin{array}{l}\text { Liver grafts from } \\
\text { extended criteria } \\
\text { donors not utilized } \\
\text { for approved } \\
\text { indications }\end{array}$ & $\begin{array}{l}\text { Whole liver from } \\
\text { deceased donor }\end{array}$ & $\begin{array}{l}\text { LT from cadaveric } \\
\text { donors }\end{array}$ & $\begin{array}{l}\text { Living donors or } \\
\text { cadaveric donors }\end{array}$ & $\begin{array}{l}\text { LT from cadaveric } \\
\text { donors }\end{array}$ \\
\hline
\end{tabular}




\begin{tabular}{|c|c|c|c|c|c|c|c|c|c|}
\hline & $\begin{array}{l}\text { Toronto NCT } \\
02864485\end{array}$ & $\begin{array}{l}\text { TRANSMET } \\
\text { NCT02597348 }\end{array}$ & $\begin{array}{l}\text { RAPID } \\
\text { NCT02215889 }\end{array}$ & $\begin{array}{l}\text { LIVER-T(W)O- } \\
\text { HEAL } \\
\text { NCT03488953 }\end{array}$ & $\begin{array}{l}\text { SOULMATE } \\
\text { NCT04161092 }\end{array}$ & $\begin{array}{l}\text { SECA III } \\
\text { NCT03494946 }\end{array}$ & $\begin{array}{l}\text { COLT } \\
\text { NCT03803436 }\end{array}$ & $\begin{array}{l}\text { RAPID-PADOVA } \\
\text { NCT04865471 }\end{array}$ & $\begin{array}{l}\text { MELODIC } \\
\text { NCT04870879 }\end{array}$ \\
\hline $\begin{array}{l}\text { Main inclusion } \\
\text { criteria }\end{array}$ & $\begin{array}{l}\text { - ECOG 0-1 } \\
\text { - Proven } \\
\text { colorectal liver } \\
\text { metastases } \\
\text { - Primary tumor } \\
\text { stage } \leq \text { T4a } \\
\text { - Time from } \\
\text { primary to LT } \geq 6 \\
\text { months } \\
\text { - No major } \\
\text { vascular invasion } \\
\text { - Metastases } \\
\text { isolated to liver } \\
\text { - Previous CT for } \\
\geq 3 \text { months with } \\
\text { stability or } \\
\text { regression of } \\
\text { CRLMs } \\
\text { - CEA values are } \\
\text { stable or } \\
\text { decreasing } \\
\text { - BRAF wild-type }\end{array}$ & $\begin{array}{l}\text { - ECOG } 0 \text { or } 1 \\
\text { - } \geq 18 \text { and } \leq 65 \\
\text { years } \\
\text { - Histologically } \\
\text { proved } \\
\text { adenocarcinoma } \\
\text { in colon or } \\
\text { rectum } \\
\text { - BRAF wild-type } \\
\text { - High-standard } \\
\text { oncological } \\
\text { surgical } \\
\text { resection of the } \\
\text { primary* } \\
\text { - No local } \\
\text { recurrence on } \\
\text { colonoscopy } \\
\text { - } \geq 3 \text { months of } \\
\text { tumor control } \\
\text { during the last } \\
\text { CT line: stable or } \\
\text { partial response } \\
\text { on RECIST } \\
\text { criteria } \\
\text { - } \leq 2 \text { lines of CT } \\
\text { for metastatic } \\
\text { disease } \\
\text { - CEA <80 } \\
\text { microg/L or a } \\
\text { decrease } \geq 50 \% \\
\text { - No extrahepatic } \\
\text { tumor }\end{array}$ & $\begin{array}{l}\text { - ECOG } 0 \text { or } 1 \\
\text { - Histologically } \\
\text { proved } \\
\text { adenocarcinoma } \\
\text { in the colon or } \\
\text { rectum } \\
\text { - No extrahepatic } \\
\text { or local } \\
\text { recurrence } \\
\text { (except 1-3 } \\
\text { resectable lung } \\
\text { lesions all } \\
<15 \mathrm{~mm} \text { ) } \\
\text { - At least } 8 \text { weeks } \\
\text { of CT }\end{array}$ & $\begin{array}{l}\text { - Stable disease } \\
\text { after } 8 \text { weeks of } \\
\text { CT } \\
\text { - Primary tumor } \\
\text { < pT3, N1 } \\
\text { - No extrahepatic } \\
\text { tumor burden } \\
\text { (except } \\
\text { resectable lung } \\
\text { metastases) }\end{array}$ & $\begin{array}{l}\text { - ECOG } 0 \text { or } 1 \\
\text { - } \geq 18 \text { years } \\
\text { - Histologically } \\
\text { proved } \\
\text { adenocarcinoma } \\
\text { in the colon or } \\
\text { rectum } \\
\text { - Primary tumor } \\
\text { removed with an } \\
\text { RO resection } \\
\text { - No extrahepatic } \\
\text { or local } \\
\text { recurrence } \\
\text { - At least } 2 \\
\text { months of CT } \\
\text { with no signs of } \\
\text { progression } \\
\text { - >1 year from } \\
\text { initial diagnosis } \\
\text { - BRAF wild-type }\end{array}$ & $\begin{array}{l}\text { - ECOG } 0 \text { or } 1 \\
\text { - Histologically } \\
\text { proved } \\
\text { adenocarcinoma } \\
\text { in the colon or } \\
\text { rectum } \\
\text { - No extrahepatic } \\
\text { or local } \\
\text { recurrence } \\
\text { (except } \\
\text { resectable lung } \\
\text { lesions all < } \\
\text { 15 mm). } \\
\text { - All patients } \\
\text { should have } \\
\text { progressive } \\
\text { disease } \\
\text { according to } \\
\text { RECIST criteria, } \\
\text { or intolerance to } \\
\text { 1. line CT. } \\
\text { - Patients must be } \\
\text { randomized } \\
\text { before } \\
\text { evaluation 8-12 } \\
\text { weeks after } \\
\text { starting the } \\
\text { second-line } \\
\text { chemotherapy }\end{array}$ & $\begin{array}{l}\text { - ECOG } 0 \\
\text { - Histologically } \\
\text { confirmed } \\
\text { non-mucinous } \\
\text { colon } \\
\text { adenocarcinoma } \\
\text { - pT1-3, pNO or } \\
\text { pN1 } \\
\text { (metastases in < } \\
4 \text { regional lymph } \\
\text { nodes), } \\
\text { confirmed RO } \\
\text { resection. } \\
\text { - RAS and BRAF } \\
\text { wild-type } \\
\text { - Objective } \\
\text { response } \\
\text { according to } \\
\text { RECIST 1.1 to } \\
\text { first-line } \\
\text { treatment, with } \\
\text { sustained } \\
\text { response for at } \\
\text { least } 4 \text { months, } \\
\text { OR disease } \\
\text { control (CR + } \\
\text { PR }+ \text { SD) during } \\
\text { the second-line } \\
\text { treatment for at } \\
\text { least } 4 \text { months. } \\
\text { - A maximum of } \\
\text { two prior CT } \\
\text { treatment lines. } \\
\text { - CEA < } 50 \text { ng/ml }\end{array}$ & $\begin{array}{l}\text { - ECOG } 0 \text { or } 1 \\
\text { - } \geq 18 \text { and <70 } \\
\text { years } \\
\text { - BRAF wild-type } \\
\text { - High standard } \\
\text { oncological } \\
\text { surgical } \\
\text { resection of the } \\
\text { primary* } \\
\text { - Histologically } \\
\text { proved } \\
\text { adenocarcinoma } \\
\text { in the colon or } \\
\text { rectum } \\
\text { - Time from } \\
\text { primary surgery } \\
\text { to WL } 26 \\
\text { months } \\
\text { - At least } 2 \\
\text { months of stable } \\
\text { disease or } \\
\text { partial response } \\
\text { according to } \\
\text { RECIST } 1.1 \\
\text { - At least } 1 \text { CT line } \\
\text { treatment (3 } \\
\text { months) } \\
\text { - CEA stability or } \\
\text { reduction } \\
\text { - No extrahepatic } \\
\text { disease, expect } \\
\text { for lung } \\
\text { metastases (up } \\
\text { to three } \\
\text { resectable } \\
\text { nodules or liable } \\
\text { to radiotherapy } \\
\text { with no } \\
\text { progression after } \\
3 \text { months) } \\
\text { - Resected hilar } \\
\text { hepatic } \\
\text { adenopathy with } \\
\text { no progression } \\
\text { after } 3 \text { months }\end{array}$ & 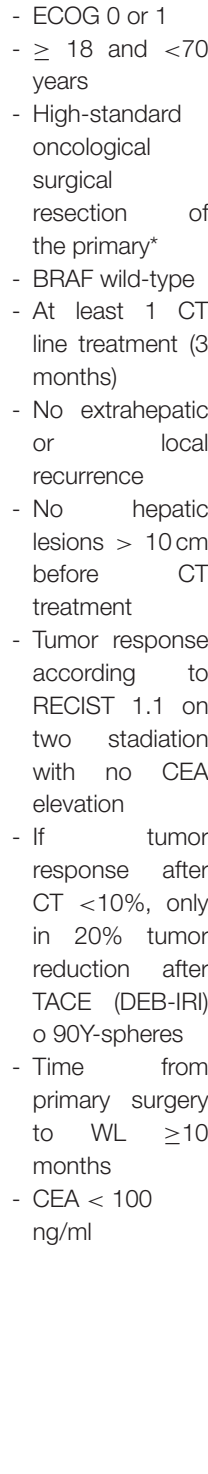 \\
\hline
\end{tabular}


TABLE 3 | Continued

\begin{tabular}{|c|c|c|c|c|c|c|c|c|c|}
\hline & $\begin{array}{l}\text { Toronto NCT } \\
02864485\end{array}$ & $\begin{array}{l}\text { TRANSMET } \\
\text { NCT02597348 }\end{array}$ & $\begin{array}{l}\text { RAPID } \\
\text { NCT02215889 }\end{array}$ & $\begin{array}{l}\text { LIVER-T(W)O- } \\
\text { HEAL } \\
\text { NCT03488953 }\end{array}$ & $\begin{array}{l}\text { SOULMATE } \\
\text { NCT04161092 }\end{array}$ & $\begin{array}{l}\text { SECA III } \\
\text { NCT03494946 }\end{array}$ & $\begin{array}{l}\text { COLT } \\
\text { NCT03803436 }\end{array}$ & $\begin{array}{l}\text { RAPID-PADOVA } \\
\text { NCT04865471 }\end{array}$ & $\begin{array}{l}\text { MELODIC } \\
\text { NCT04870879 }\end{array}$ \\
\hline $\begin{array}{l}\text { Main exclusion } \\
\text { criteria }\end{array}$ & $\begin{array}{l}\text { - General } \\
\text { contraindication } \\
\text { to LT } \\
\text { - Prior lung } \\
\text { resection } \\
\text { - Progression of } \\
\text { CRLMs at any } \\
\text { timepoint prior } \\
\text { to LT } \\
\text { - History of HIV or } \\
\text { chronic } \\
\text { HBV/HCV. }\end{array}$ & $\begin{array}{l}\text { - General } \\
\text { contraindication } \\
\text { to LT } \\
\text { - Patients not } \\
\text { having received } \\
\text { standard } \\
\text { treatment for the } \\
\text { primary CRC } \\
\text { - Extrahepatic } \\
\text { metastatic } \\
\text { disease or local } \\
\text { relapse }\end{array}$ & $\begin{array}{l}\text { - General } \\
\text { contraindication } \\
\text { to LT } \\
\text { - Weight loss } \\
>10 \% \text { the last } 6 \\
\text { months } \\
\text { - } \text { BMI > } 30 \\
\text { - Palliative } \\
\text { resection of } \\
\text { primary CRC } \\
\text { tumor. }\end{array}$ & $\begin{array}{l}\text { - General } \\
\text { contraindication } \\
\text { to LT } \\
\text { - Macroscopic } \\
\text { vascular tumor } \\
\text { infiltration } \\
\text { - Tumor } \\
\text { progression } \\
\text { during CT }\end{array}$ & $\begin{array}{l}\text { - General } \\
\text { contraindication } \\
\text { to LT } \\
\text { - Extrahepatic } \\
\text { disease } \\
\text { - Weight loss } \\
>10 \% \text { the last } 6 \\
\text { months } \\
\text { - Liver metastases } \\
\text { larger than } \\
10 \mathrm{~cm} \text {. } \\
\text { - Pathological } \\
\text { lymphatic nodes } \\
\text { in the abdomen. } \\
\text { - Microsatellite } \\
\text { instability - } \\
\text { previous } \\
\text { transplantation }\end{array}$ & $\begin{array}{l}\text { - General } \\
\text { contraindication } \\
\text { to LT } \\
\text { - Weight loss } \\
>10 \% \text { the last } 6 \\
\text { months } \\
\text { - BMl }>30 \\
\text { - Resection of } \\
\text { local relapse or } \\
\text { non-hepatic } \\
\text { metastasis } \\
\text { within } 2 \text { years or } \\
\text { resection of } \\
\text { pulmonary/liver } \\
\text { hilus lymph node } \\
\text { metastases }<1 \\
\text { year } \\
\text { - Liver } \\
\text { lesion }>10 \mathrm{~cm} \\
\text { - } 3 \text { negative } \\
\text { prognostic } \\
\text { factors } \\
\text { (CEA }>80, \text { less } \\
\text { than } 2 \text { years } \\
\text { from diagnosis, } \\
\text { diameter of } \\
\text { largest liver } \\
\text { lesion }>5.5 \mathrm{~cm} \text { ). }\end{array}$ & $\begin{array}{l}\text { - General } \\
\text { contraindication } \\
\text { to LT } \\
\text { - Hereditary CRC } \\
\text { syndromes } \\
\text { - Extrahepatic } \\
\text { metastatic } \\
\text { disease or } \\
\text { primary tumor } \\
\text { local relapse. } \\
\text { - Active } \\
\text { intravenous or } \\
\text { alcohol abusers } \\
\text { - HIV infection }\end{array}$ & $\begin{array}{l}\text { - General } \\
\text { contraindication } \\
\text { to LT } \\
\text { - Patients not } \\
\text { having received } \\
\text { standard } \\
\text { treatment for the } \\
\text { primary CRC } \\
\text { - BMI > } 30 \\
\text { - Weight loss } \\
>10 \% \text { the last } 6 \\
\text { months }\end{array}$ & $\begin{array}{l}\text { - General } \\
\text { contraindication } \\
\text { to LT } \\
\text { - Patients not } \\
\text { having received } \\
\text { standard } \\
\text { treatment for } \\
\text { the primary CRC } \\
\text { - BMl }>30 \\
\text { - Weight loss } \\
>10 \% \text { the last } 6 \\
\text { months }\end{array}$ \\
\hline
\end{tabular}

*defined by : Safe margin of resection, curative resection of primary tumor according to oncological principles and TNM adequate staging.

BMI, Body Mass Index; CT, Chemotherapy; ECD, Extended Criteria Donor; ECOG, Eastern Cooperative Oncology Group; LDLT, Living Donor Liver Transplantation; LT, Liver Transplant. 
TABLE 4 | Recent guidelines and recommendations on LT for CRLMs.

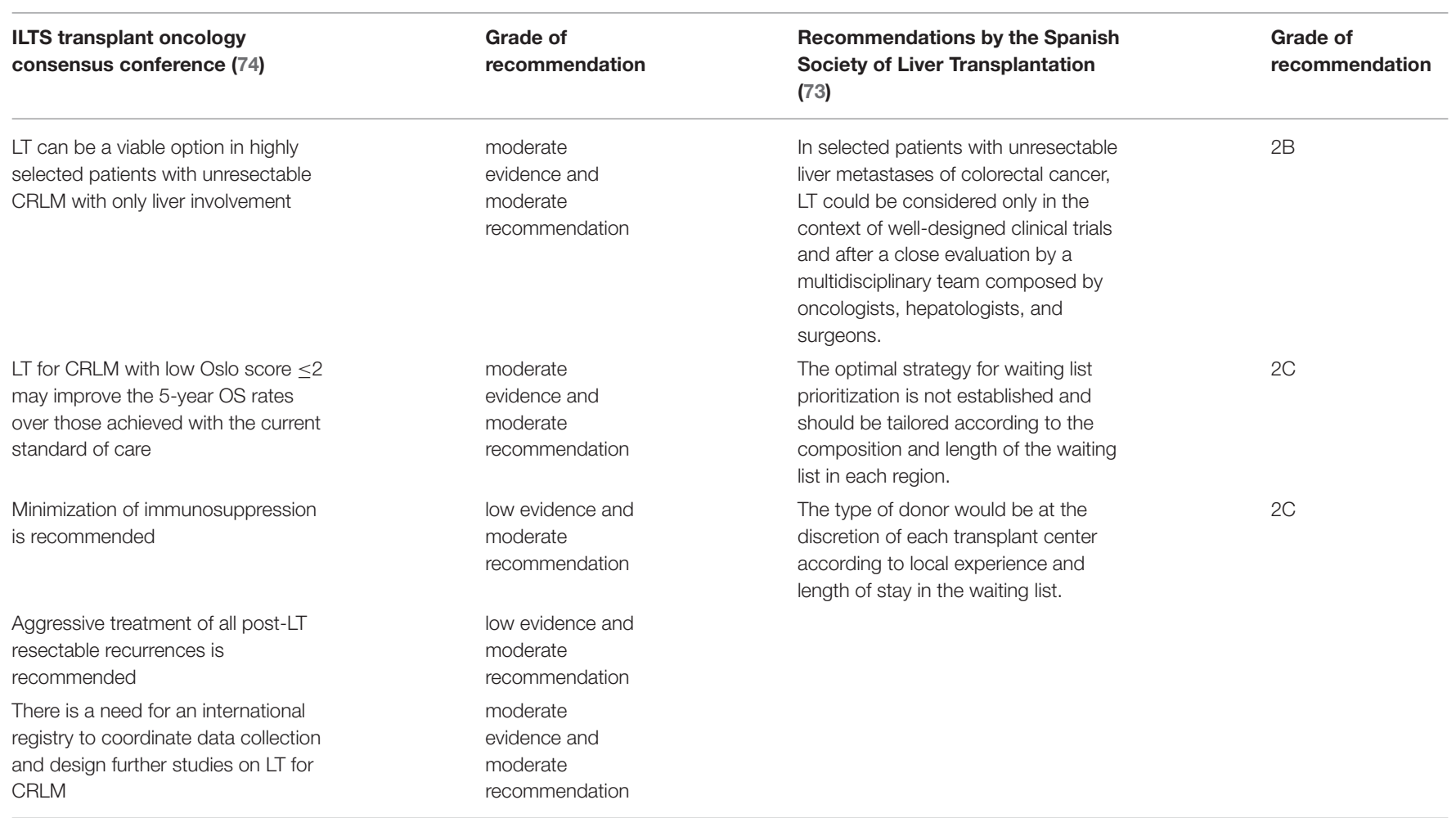

CRLM, Colon Rectal Liver Metastases; LT, Liver Transplantation; OS, Overall Survival.

Recently, a survey among the most expert liver surgeons from 23 countries has been published, evaluating the different surgical approaches among them. Importantly, $68 \%$ of them have hepatopancreatic biliary surgery and LT experiences. In particular, the aforementioned surgeons examined 10 cases of patients with CRLMs, from single metastasis to diffuse bilobar lesions. A low level of agreement was observed among them. For the same case, surgeons suggested treatments ranging from the choice of minimally invasive liver resections to complex staged liver resection. The study underlines the current difficulty to choose the best option treatments and especially the lack of consensus about the definition of resectability.

This variability could be explained because of the deficiency of high evidence studies and guidelines, and the expertise and experiences of different surgeons (59), even if non-resectability is determinant only in the context of organ shortage.

The main factor that indicates the benefit of LT for CRLMs is OS, which means that patients could benefit from LT no matter non-resectability. Resectability can be achieved in bilobar and multiple CRLMs by various complex techniques, including liver augmentation (portal vein embolization, liver venous deprivation, ALPPS). However, the outcome after resection is still highly variable, and OS is greatly affected by hepatic tumor load and the number of CRLMs (60-62). For example, ALPPS has the potential to increase the rate of resectability, but the 5-year OS is reported to be $30 \%$ compared to $83 \%$ in the SECA-II and $60 \%$ in the SECA-I study $(36,63)$. This leads to the interesting scenario wherein future LT may become the first treatment of choice regardless of the technical resectability of the tumor in selected patients. For example, it has recently been shown that LT in non-resectable CRLMs is superior to portal vein embolization and liver resection in resectable disease in patients with high tumor load (64).

The resectability of the CRLMs is not the only variable to take into account when LT is considered as a treatment option. The correct selection of patients affected by CRLM is the cornerstone to achieve the best benefit from LT, as for LT for HCC. SECA-I, with relatively broad inclusion criteria, obtained a $60 \%$ 5-year OS; in the SECA-II, with more strict criteria, the 5 -year OS increased to $83 \%$. In a recent subanalysis of the SECA-I and SECA-II patients, Dueland et al., compared the Fong Clinical Risk Score, total PET liver uptake (metabolic tumor volume, MTV), and Oslo score in terms of OS, DFS, and survival after relapse. Considering 13 of the 19 patients (14 and five patients from SECA-I and SECA-II), a Kaplan-Meier OS of 100, 78, and $67 \%$ at 5 years was obtained in patients with Fong Clinical Risk Score 0-2, MTV-low group, and Oslo score $0-2$, respectively, with a median follow-up of 85 months (65).

Narrowing the inclusion criteria leads to a better patient selection and outcome and to the detriment of patients that would be eligible to LT. As for HCC, the selection of which patient would benefit most from LT is still a matter of debate (65-67), and transplant benefit could be the guide to the correct patient selection for LT $(65,68-70)$. The Oslo score proposed in the SECA study has to be integrated and validated in the ongoing trials, to define the ideal candidate for LT for CRLM. 
On the other hand, the expansion of the inclusion criteria leads inevitably to a worsening of the OS after LT. Recently, Smedman et al. published a series derived from the SECA-II study (arm D) with 10 patients excluded from the SECA-II criteria. In arm $\mathrm{D}$, the main patients who had resectable pulmonary metastases and no response to CT were also eligible for inclusion. Most of the patients had a $\mathrm{pT} 3, \mathrm{pN} 2$, poorly differentiated, rightsided primary tumor, and nine of 10 patients were transplanted with ECD grafts (32).

Two patients had a BRAF mutation, and two had a progression of the disease on the last line of chemotherapy at the time of LT. In this setting, compared to the result of the SECA-I and II, the worsening of the prognosis was dramatic: The median DFS and median OS were 4 and 18 months, respectively.

To note, the Fong score of SECA arm D was similar to that of SECA-I, and patients with an Oslo score of 1-2 had significantly shorter OS than patients with a similar Oslo score in the SECA-I study.

This is further evidence that we should take into account features different from those described by Fong and Oslo scores, such as tumor location, histological differentiation, and lymph node status of the primary tumor (32).

Another point of discussion is the role and the combination of LT and chemotherapy. In the SECA-II, the adjuvant CT was not evaluated, based on the results of the EORTC 40983 study (48). The study showed no difference in OS with the addition of adjuvant CT with FOLFOX compared with surgery alone for patients with resectable CRLMs. In the SECA-II, most of the patients received extensive neoadjuvant CT especially with oxaliplatin and 5-FU regimens, which are the only chemotherapy drugs that significantly improved the OS in the CRLMs. However, in the SECA-II, the authors state that based on the EORTC 40983 study and the extensive pre-LT CT regimens, adding 5-FU or 5 -FU combined with oxaliplatin would have had not to impact on the OS, increasing only the toxicity post-LT. However, as S. Jegatheeswaran and A. Siriwardena noted, the patient in the SECA-II cohort experienced a more aggressive approach than in the EORTC 40983 study, treating pulmonary metastases with resection and performing surgical regional lymphadenectomy at LT, making the two cohorts difficult to compare $(57,58)$. As

\section{REFERENCES}

1. Dexiang Z, Li R, Ye W, Haifu W, Yunshi Z, Qinghai Y, et al. Outcome of patients with colorectal liver metastasis: analysis of 1,613 consecutive cases. Ann Surg Oncol. (2012) 19:2860-8. doi: 10.1245/s10434-012-2356-9

2. Cronin KA, Lake AJ, Scott S, Sherman RL, Noone AM, Howlader N, et al. Annual report to the nation on the status of cancer, part i: national cancer statistics. Cancer. (2018) 124:2785-800. doi: 10.1002/cncr.31551

3. Garden OJ, Rees M, Poston GJ, Mirza D, Saunders M, Ledermann J, et al. Guidelines for resection of colorectal cancer liver metastases. Gut. (2006) 55 (Suppl. 3):iii1-8. doi: 10.1136/gut.2006.098053

4. Line PD, Ruffolo LI, Toso C, Dueland S, Nadalin S, Hernandez-Alejandro R. Liver transplantation for colorectal liver metastases: what do we need to know? Int J Surg. (2020) 82S:87-92. doi: 10.1016/j.ijsu.2020.03.079

5. Lang H, de Santibanes E, Schlitt HJ, Malago M, van Gulik T, Machado MA, et al. 10th Anniversary of ALPPS-lessons learned and quo Vadis. Ann Surg. (2019) 269:114-9. doi: 10.1097/SLA.0000000000002797 noted by Gorgen et al., the good results in terms of OS should also be evaluated considering the role of chemotherapy. In the SECA-II, the median number and the maximum diameter of the CRLMs consistently decreased after neoadjuvant chemotherapy (from 12 to 5 lesions and from 4.5 to $2.5 \mathrm{~cm}$, respectively). The downstaging was confirmed at pathological evaluation after LT (71). However, the impact and the correct timing of CT before and after LT are still under evaluation, and to date, no sufficient data are available to make some recommendations. A trial that is evaluating the role of adjuvant CT after LT for CRLMs is ongoing (Transmet, NCT 02597348).

Furthermore, the OS of patients affected by non-resectable CRLMs treated with only CT is low, but it is unknown the results of the CT in the same highly selected patients selected for LT (36).

Compagnons Hepato-Biliaires described a long-term DFS after LT for CRLMs with patients (four of 12 patients) treated with post-transplant adjuvant chemotherapy, oxaliplatin, and/or irinotecan, including CT (55).

Recently, Brandi et al. reported the good outcome and safety of three patients treated after LT for CRLMs with chemotherapy, including cytotoxic doublet or triplet (e.g., FOLFOX, FOLFOXIRI).

The concomitant immunosuppressive use did not seem to interfere with compliance to chemotherapy (72).

To conclude, the role of LT in the treatment of CRLMs is still under evaluation, with a series of clinical trials ongoing. Recently, national and international guidelines are taking into account this therapeutic option: The ILTS Transplant Oncology Consensus Conference and the Spanish Society of Liver Transplantation published their recommendations for LT for CRLMs $(73,74)$, and the treatment algorithm of CRLMs has been recently proposed (75) (see Table 4).

\section{AUTHOR CONTRIBUTIONS}

MF involved in study design and drafting of the manuscript. $\mathrm{AV}$ and $\mathrm{UC}$ revised the manuscript. EG, FD'A, RB, AB, SL, FB, and PF reviewed and approved the manuscript. All authors contributed to the article and approved the submitted version.
6. Butte JM, Gonen M, Allen PJ, Peter Kingham T, Sofocleous CT, DeMatteo RP, et al. Recurrence after partial hepatectomy for metastatic colorectal cancer: potentially curative role of salvage repeat resection. Ann Surg Oncol. (2015) 22:2761-71. doi: 10.1245/s10434-0154370-1

7. Eker HH. Repeat hepatectomy for recurrent colorectal metastases. Br J Surg. (2013) 100:818-9. doi: 10.1002/bjs.9087

8. Khatri VP, Petrelli NJ, Belghiti J. Extending the frontiers of surgical therapy for hepatic colorectal metastases: is there a limit? J Clin Oncol. (2005) 23:84909. doi: 10.1200/JCO.2004.00.6155

9. Fong Y, Fortner J, Sun RL, Brennan MF, Blumgart LH. Clinical score for predicting recurrence after hepatic resection for metastatic colorectal cancer: analysis of 1001 consecutive cases. Ann Surg. (1999) 230:30918. doi: 10.1097/00000658-199909000-00004

10. Nordlinger B, Guiguet M, Vaillant JC, Balladur P, Boudjema K, Bachellier $\mathrm{P}$, et al. Surgical resection of colorectal carcinoma metastases to the liver. A prognostic scoring system to improve case selection, based on 
1568 patients. Association Francaise de Chirurgie. Cancer. (1996) 77:125462. doi: 10.1002/(SICI)1097-0142(19960401)77:7<1254::AID-CNCR5>3.0. $\mathrm{CO} ; 2-\mathrm{I}$

11. Nagashima I, Takada $T$, Adachi M, Nagawa $H$, Muto $T$, Okinaga K. Proposal of criteria to select candidates with colorectal liver metastases for hepatic resection: comparison of our scoring system to the positive number of risk factors. World J Gastroenterol. (2006) 12:6305-9. doi: 10.3748/wjg.v12.i39.6305

12. Konopke R, Kersting S, Distler M, Dietrich J, Gastmeier J, Heller A, et al. Prognostic factors and evaluation of a clinical score for predicting survival after resection of colorectal liver metastases. Liver Int. (2009) 29:89102. doi: 10.1111/j.1478-3231.2008.01845.x

13. Moris D, Tsilimigras DI, Chakedis J, Beal EW, Felekouras E, Vernadakis S, et al. Liver transplantation for unresectable colorectal liver metastases: a systematic review. J Surg Oncol. (2017) 116:288-97. doi: 10.1002/jso.24671

14. Hibi $T$, Itano $O$, Shinoda $M$, Kitagawa $Y$. Liver transplantation for hepatobiliary malignancies: a new era of "transplant oncology" has begun. Surg Today. (2017) 47:403-15. doi: 10.1007/s00595-016-1337-1

15. Nadalin S, Konigsrainer A, Capobianco I, Settmacher U, Rauchfuss F. Auxiliary living donor liver transplantation combined with two-stage hepatectomy for unresectable colorectal liver metastases. Curr Opin Organ Transplant. (2019) 24:651-8. doi: 10.1097/MOT.0000000000000695

16. Yang Z, Wang Y, Ye Q. Liver transplantation for progressive unresectable colorectal liver metastases: case report and review of the literature. Transplant Proc. (2019) 51:3124-30. doi: 10.1016/j.transproceed.2019.06.003

17. Abreu P, Gorgen A, Oldani G, Hibi T, Sapisochin G. Recent advances in liver transplantation for cancer: the future of transplant oncology. JHEP Rep. (2019) 1:377-91. doi: 10.1016/j.jhepr.2019.07.004

18. Muhlbacher F, Huk I, Steininger R, Gnant M, Gotzinger P, Wamser P, et al. Is orthotopic liver transplantation a feasible treatment for secondary cancer of the liver? Transplant Proc. (1991) 23:1567-8.

19. Bokemeyer C, Kohne CH, Ciardiello F, Lenz HJ, Heinemann V, Klinkhardt U, et al. FOLFOX4 plus cetuximab treatment and RAS mutations in colorectal cancer. Eur J Cancer. (2015) 51:1243-52. doi: 10.1016/j.ejca.2015.04.007

20. Van Cutsem E, Cervantes A, Adam R, Sobrero A, Van Krieken JH, Aderka D, et al. ESMO consensus guidelines for the management of patients with metastatic colorectal cancer. Ann Oncol. (2016) 27:1386422. doi: 10.1093/annonc/mdw235

21. Hurwitz H, Fehrenbacher L, Novotny W, Cartwright T, Hainsworth J, Heim W, et al. Bevacizumab plus irinotecan, fluorouracil, and leucovorin for metastatic colorectal cancer. N Engl J Med. (2004) 350:2335-42. doi: 10.1056/NEJMoa032691

22. De Greef K, Rolfo C, Russo A, Chapelle T, Bronte G, Passiglia F, et al. Multidisciplinary management of patients with liver metastasis from colorectal cancer. World J Gastroenterol. (2016) 22:7215-25. doi: 10.3748/wjg.v22.i32.7215

23. Lang H, Baumgart J, Heinrich S, Tripke V, Passalaqua M, Maderer A, et al. Extended Molecular Profiling Improves Stratification and Prediction of Survival After Resection of Colorectal Liver Metastases. Ann Surg. (2019) 270:799-805. doi: 10.1097/SLA.0000000000003527

24. Chun YS, Passot G, Yamashita S, Nusrat M, Katsonis P, Loree JM, et al. Deleterious effect of RAS and evolutionary high-risk TP53 double mutation in colorectal liver metastases. Ann Surg. (2019) 269:91723. doi: 10.1097/SLA.0000000000002450

25. Geissler EK, Schnitzbauer AA, Zulke C, Lamby PE, Proneth A, Duvoux C, et al. Sirolimus use in liver transplant recipients with hepatocellular carcinoma: a randomized, multicenter, open-label phase 3 trial. Transplantation. (2016) 100:116-25. doi: 10.1097/TP.0000000000000965

26. Liang W, Wang D, Ling X, Kao AA, Kong Y, Shang Y, et al. Sirolimus-based immunosuppression in liver transplantation for hepatocellular carcinoma: a meta-analysis. Liver Transpl. (2012) 18:62-9. doi: 10.1002/lt.22441

27. Schnitzbauer AA, Zuelke C, Graeb C, Rochon J, Bilbao I, Burra P, et al. A prospective randomised, open-labeled, trial comparing sirolimus-containing versus mTOR-inhibitor-free immunosuppression in patients undergoing liver transplantation for hepatocellular carcinoma. BMC Cancer. (2010) 10:190. doi: 10.1186/1471-2407-10-190

28. Motzer RJ, Escudier B, Oudard S, Hutson TE, Porta C, Bracarda S, et al. Phase 3 trial of everolimus for metastatic renal cell carcinoma : final results and analysis of prognostic factors. Cancer. (2010) 116:425665. doi: 10.1002/cncr.25219

29. Spitzer AL, Dick AA, Bakthavatsalam R, Halldorson JB, Salvalaggio PR, Reyes JD, et al. Intraoperative portal vein blood flow predicts allograft and patient survival following liver transplantation. HPB. (2010) 12:16673. doi: 10.1111/j.1477-2574.2009.00137.x

30. Dueland S, Guren TK, Hagness M, Glimelius B, Line PD, Pfeiffer $\mathrm{P}$, et al. Chemotherapy or liver transplantation for nonresectable liver metastases from colorectal cancer? Ann Surg. (2015) 261:956-60. doi: 10.1097/SLA.0000000000000786

31. Hagness M, Foss A, Line PD, Scholz T, Jorgensen PF, Fosby B, et al. Liver transplantation for nonresectable liver metastases from colorectal cancer. Ann Surg. (2013) 257:800-6. doi: 10.1097/SLA.0b013e3182823957

32. Smedman TM, Line PD, Hagness M, Syversveen T, Grut H, Dueland S. Liver transplantation for unresectable colorectal liver metastases in patients and donors with extended criteria (SECA-II arm D study). BJS Open. (2020) 4:467-77. doi: 10.1002/bjs5.50278

33. Dueland S, Syversveen T, Solheim JM, Solberg S, Grut H, Bjornbeth $\mathrm{BA}$, et al. Survival following liver transplantation for patients with nonresectable liver-only colorectal metastases. Ann Surg. (2020) 271:2128. doi: 10.1097/SLA.0000000000003404

34. Grut H, Dueland S, Line PD, Revheim ME. The prognostic value of F-FDG PET/CT prior to liver transplantation for nonresectable colorectal liver metastases. Eur J Nucl Med Mol Imaging. (2018) 45:21825. doi: 10.1007/s00259-017-3843-9

35. Fosby B, Melum E, Bjoro K, Bennet W, Rasmussen A, Andersen IM, et al. Liver transplantation in the Nordic countries - an intention to treat and post-transplant analysis from The Nordic Liver Transplant Registry 1982-2013. Scand J Gastroenterol. (2015) 50:797-808. doi: 10.3109/00365521.2015.1036359

36. Azoulay D, Lim C. Comment on "Survival following liver transplantation for patients with nonresectable liver-only colorectal metastases": shaking the coconut tree. Ann Surg. (2020) 271:e1224. doi: 10.1097/SLA.0000000000003605

37. Line PD, Hagness $M$, Berstad AE, Foss A, Dueland $S$. A novel concept for partial liver transplantation in nonresectable colorectal liver metastases: the RAPID concept. Ann Surg. (2015) 262:e5-9. doi: 10.1097/SLA.0000000000001165

38. Dueland S, Line PD. Liver segment $2+3$ living donation in liver transplantation for colorectal liver metastases. Hepatobiliary Surg Nutr. (2020) 9:382-4. doi: 10.21037/hbsn.2019.11.15

39. Terpstra OT, Schalm SW, Weimar W, Willemse PJ, Baumgartner $\mathrm{D}$, Groenland $\mathrm{TH}$, et al. Auxiliary partial liver transplantation for end-stage chronic liver disease. $N$ Engl J Med. (1988) 319:1507-11. doi: 10.1056/NEJM198812083192303

40. Nadalin S, Settmacher U, Rauchfuss F, Balci D, Konigsrainer A, Line PD. RAPID procedure for colorectal cancer liver metastasis. Int J Surg. (2020) 82S:93-6. doi: 10.1016/j.ijsu.2020.03.078

41. Rauchfuss F, Nadalin S, Konigsrainer A, Settmacher U. Living donor liver transplantation with two-stage hepatectomy for patients with isolated, irresectable colorectal liver-the LIVER-T(W)O-HEAL study. World J Surg Oncol. (2019) 17:11. doi: 10.1186/s12957-018-1549-5

42. Konigsrainer A, Templin S, Capobianco I, Konigsrainer I, Bitzer M, Zender L, et al. Paradigm shift in the management of irresectable colorectal liver metastases: living donor auxiliary partial orthotopic liver transplantation in combination with two-stage hepatectomy (LD-RAPID). Ann Surg. (2019) 270:327-32. doi: 10.1097/SLA.0000000000002861

43. Ravaioli M, Brandi G, Siniscalchi A, Renzulli M, Bonatti C, Fallani G, et al. Heterotopic segmental liver transplantation on splenic vessels after splenectomy with delayed native hepatectomy after graft regeneration: a new technique to enhance liver transplantation. Am J Transplant. (2020) 21:870-5. doi: 10.1111/ajt.16222

44. Ravaioli M, Fallani G, Cerri M, Prosperi E, Serra C, D’Errico A, et al. Two surgical techniques are better than one: RAVAS and RAPID are answers for the same issue. Am J Transplant. (2020) 21:905-6. doi: 10.1111/ajt.16301

45. Schnitzbauer AA, Lang SA, Goessmann H, Nadalin S, Baumgart J, Farkas SA, et al. Right portal vein ligation combined with in situ splitting induces rapid left lateral liver lobe hypertrophy enabling 2-staged extended right 
hepatic resection in small-for-size settings. Ann Surg. (2012) 255:40514. doi: 10.1097/SLA.0b013e31824856f5

46. Schadde E, Ardiles V, Slankamenac K, Tschuor C, Sergeant G, Amacker $\mathrm{N}$, et al. ALPPS offers a better chance of complete resection in patients with primarily unresectable liver tumors compared with conventional-staged hepatectomies: results of a multicenter analysis. World J Surg. (2014) 38:15109. doi: 10.1007/s00268-014-2513-3

47. Quan D, Gallinger S, Nhan C, Auer RA, Biagi JJ, Fletcher GG, et al. The role of liver resection for colorectal cancer metastases in an era of multimodality treatment: a systematic review. Surgery. (2012) 151:86070. doi: 10.1016/j.surg.2011.12.018

48. Nordlinger B, Sorbye H, Glimelius B, Poston GJ, Schlag PM, Rougier P, et al. Perioperative FOLFOX4 chemotherapy and surgery versus surgery alone for resectable liver metastases from colorectal cancer (EORTC 40983): longterm results of a randomised, controlled, phase 3 trial. Lancet Oncol. (2013) 14:1208-15. doi: 10.1016/S1470-2045(13)70447-9

49. Nordlinger B, Sorbye H, Glimelius B, Poston GJ, Schlag PM, Rougier $\mathrm{P}$, et al. Perioperative chemotherapy with FOLFOX4 and surgery versus surgery alone for resectable liver metastases from colorectal cancer (EORTC Intergroup trial 40983): a randomised controlled trial. Lancet. (2008) 371:1007-16. doi: 10.1016/S0140-6736(08)60455-9

50. Settmacher U, Dittmar Y, Knosel T, Schone U, Heise M, Jandt K, et al. Predictors of long-term survival in patients with colorectal liver metastases: a single center study and review of the literature. Int J Colorectal Dis. (2011) 26:967-81. doi: 10.1007/s00384-011-1195-7

51. Grut H, Solberg S, Seierstad T, Revheim ME, Egge TS, Larsen SG, et al. Growth rates of pulmonary metastases after liver transplantation for unresectable colorectal liver metastases. Br J Surg. (2018) 105:295301. doi: 10.1002/bjs.10651

52. D'Angelica $M$, Kornprat $\mathrm{P}$, Gonen $\mathrm{M}$, DeMatteo RP, Fong $\mathrm{Y}$, Blumgart LH, et al. Effect on outcome of recurrence patterns after hepatectomy for colorectal metastases. Ann Surg Oncol. (2011) 18:1096-103. doi: 10.1245/s10434-010-1409-1

53. Hagness M, Foss A, Egge TS, Dueland S. Patterns of recurrence after liver transplantation for nonresectable liver metastases from colorectal cancer. Ann Surg Oncol. (2014) 21:1323-9. doi: 10.1245/s10434-013-3449-9

54. Dueland S, Foss A, Solheim JM, Hagness M, Line PD. Survival following liver transplantation for liver-only colorectal metastases compared with hepatocellular carcinoma. Br J Surg. (2018) 105:736-42. doi: 10.1002/bjs. 10769

55. Toso C, Pinto Marques H, Andres A, Castro Sousa F, Adam R, Kalil A, et al. Liver transplantation for colorectal liver metastasis: survival without recurrence can be achieved. Liver Transpl. (2017) 23:10736. doi: 10.1002/lt.24791

56. Nieuwenhuizen S, Puijk RS, van den Bemd B, Aldrighetti L, Arntz $\mathrm{M}$, van den Boezem PB, et al. Resectability and ablatability criteria for the treatment of liver only colorectal metastases: multidisciplinary consensus document from the COLLISION trial group. Cancers. (2020) 12:1779. doi: 10.3390/cancers12071779

57. Dueland S, Line PD. Response to Comment on "Survival Following Liver Transplantation for Patients with Nonresectable Liver-only Colorectal Metastases". Ann Surg. (2020). doi: 10.1097/SLA.0000000000003953. [Epub ahead of print].

58. Jegatheeswaran S, Siriwardena AK. Comment on "survival after liver transplantation for patients with nonresectable liver-only colorectal metastases". Ann Surg. (2020) 274:e101. doi: 10.1097/SLA.0000000000003960

59. Ignatavicius P, Oberkofler CE, Chapman WC, DeMatteo RP, Clary BM, D'Angelica MI, et al. Choices of therapeutic strategies for colorectal liver metastases among expert liver surgeons: a throw of the dice? Ann Surg. (2020) 272:715-22. doi: 10.1097/SLA.0000000000004331

60. Allard MA, Adam R, Giuliante F, Lapointe R, Hubert C, Ijzermans JNM, et al. Long-term outcomes of patients with 10 or more colorectal liver metastases. Br J Cancer. (2017) 117:604-11. doi: 10.1038/bjc.2017.218

61. Sasaki K, Morioka D, Conci S, Margonis GA, Sawada Y, Ruzzenente A, et al. The tumor burden score: a new "metro-ticket" prognostic tool for colorectal liver metastases based on tumor size and number of tumors. Ann Surg. (2018) 267:132-41. doi: 10.1097/SLA.0000000000002064

62. Sasaki K, Margonis GA, Andreatos N, Zhang XF, Buettner S, Wang J, et al. The prognostic utility of the "tumor burden score" based on preoperative radiographic features of colorectal liver metastases. J Surg Oncol. (2017) 116:515-23. doi: $10.1002 /$ jso. 24678

63. Petrowsky H, Linecker M, Raptis DA, Kuemmerli C, Fritsch R, Kirimker OE, et al. First long-term oncologic results of the ALPPS procedure in a large cohort of patients with colorectal liver metastases. Ann Surg. (2020) 272:793-800. doi: 10.1097/SLA.000000000000 4330

64. Dueland S, Yaqub S, Syversveen T, Carling U, Hagness M, Brudvik KW, et al. Survival outcomes after portal vein embolization and liver resection compared with liver transplant for patients with extensive colorectal cancer liver metastases. JAMA Surg. (2021) 156:550-7. doi: 10.1001/jamasurg.2021. 0267

65. Dueland S, Grut H, Syversveen T, Hagness M, Line PD. Selection criteria related to long-term survival following liver transplantation for colorectal liver metastasis. Am J Transplant. (2020) 20:530-7. doi: 10.1111/ajt.15682

66. Finotti M, Vitale A, Volk M, Cillo U. A 2020 update on liver transplant for hepatocellular carcinoma. Expert Rev Gastroenterol Hepatol. (2020) 14:885900. doi: 10.1080/17474124.2020.1791704

67. Tournoux-Facon C, Paoletti X, Barbare JC, Bouche O, Rougier P, Dahan L, et al. Development and validation of a new prognostic score of death for patients with hepatocellular carcinoma in palliative setting. J Hepatol. (2011) 54:108-14. doi: 10.1016/j.jhep.2010.06.015

68. Serenari M, Ravaioli M. Refining selection criteria to further increase survival benefit in liver transplantation for unresectable colorectal liver metastases. Hepatobiliary Surg Nutr. (2020) 9:490-2. doi: 10.21037/hbsn.2019.11.10

69. Cillo U, Vitale A, Volk ML, Frigo AC, Grigoletto F, Brolese A, et al. The survival benefit of liver transplantation in hepatocellular carcinoma patients. Dig Liver Dis. (2010) 42:642-9. doi: 10.1016/j.dld.2010. 02.010

70. Vitale A, Cucchetti A, Qiao GL, Cescon M, Li J, Ramirez Morales R, et al. Is resectable hepatocellular carcinoma a contraindication to liver transplantation? A novel decision model based on "number of patients needed to transplant" as measure of transplant benefit. J Hepatol. (2014) 60:116571. doi: 10.1016/j.jhep.2014.01.022

71. Gorgen A, Sapisochin G. Comment on "survival following liver transplantation for patients with nonresectable liver-only colorectal metastases": what if those lesions are gone? Ann Surg. (2019) 271:e122-4. doi: 10.1097/sla.0000000000003606

72. Brandi G, Ricci AD, Rizzo A, Zanfi C, Tavolari S, Palloni A, et al. Is post-transplant chemotherapy feasible in liver transplantation for colorectal cancer liver metastases? Cancer Commun. (2020) 40:461-4. doi: 10.1002/cac2. 12072

73. Rodriguez-Peralvarez M, Gomez-Bravo MA, Sanchez-Antolin G, De la Rosa G, Bilbao I, Colmenero J, et al. Expanding indications of liver transplantation in Spain: consensus statement and recommendations by the Spanish Society of Liver Transplantation. Transplantation. (2020) 105:6027. doi: 10.1097/TP.0000000000003281

74. Hibi T, Rela M, Eason JD, Line PD, Fung J, Sakamoto S, et al. Liver transplantation for colorectal and neuroendocrine liver metastases and hepatoblastoma. Working Group Report From the ILTS Transplant Oncology Consensus Conference. Transplantation. (2020) 104:1131-5. doi: 10.1097/TP.0000000000003118

75. Petrowsky H, Fritsch R, Guckenberger M, De Oliveira ML, Dutkowski P, Clavien PA. Modern therapeutic approaches for the treatment of malignant liver tumours. Nat Rev Gastroenterol Hepatol. (2020) 17:75572. doi: $10.1038 / \mathrm{s} 41575-020-0314-8$

Conflict of Interest: The authors declare that the research was conducted in the absence of any commercial or financial relationships that could be construed as a potential conflict of interest.

Copyright (๑) 2021 Finotti, Vitale, Gringeri, D’Amico, Boetto, Bertacco, Lonardi, Bergamo, Feltracco and Cillo. This is an open-access article distributed under the terms of the Creative Commons Attribution License (CC BY). The use, distribution or reproduction in other forums is permitted, provided the original author $(s)$ and the copyright owner(s) are credited and that the original publication in this journal is cited, in accordance with accepted academic practice. No use, distribution or reproduction is permitted which does not comply with these terms. 